\title{
Teaching NeuroImages: Texting rhythm
}

\section{A common EEG finding in the era of smartphone use}

Brian Hanrahan, MD, and William O. Tatum, IV., DO, FAAN

Neurology ${ }^{\circledR}$ 2020;95:e3454-e3455. doi:10.1212/WNL.0000000000010757

Figure "Texting rhythm" in a 39-year-old woman

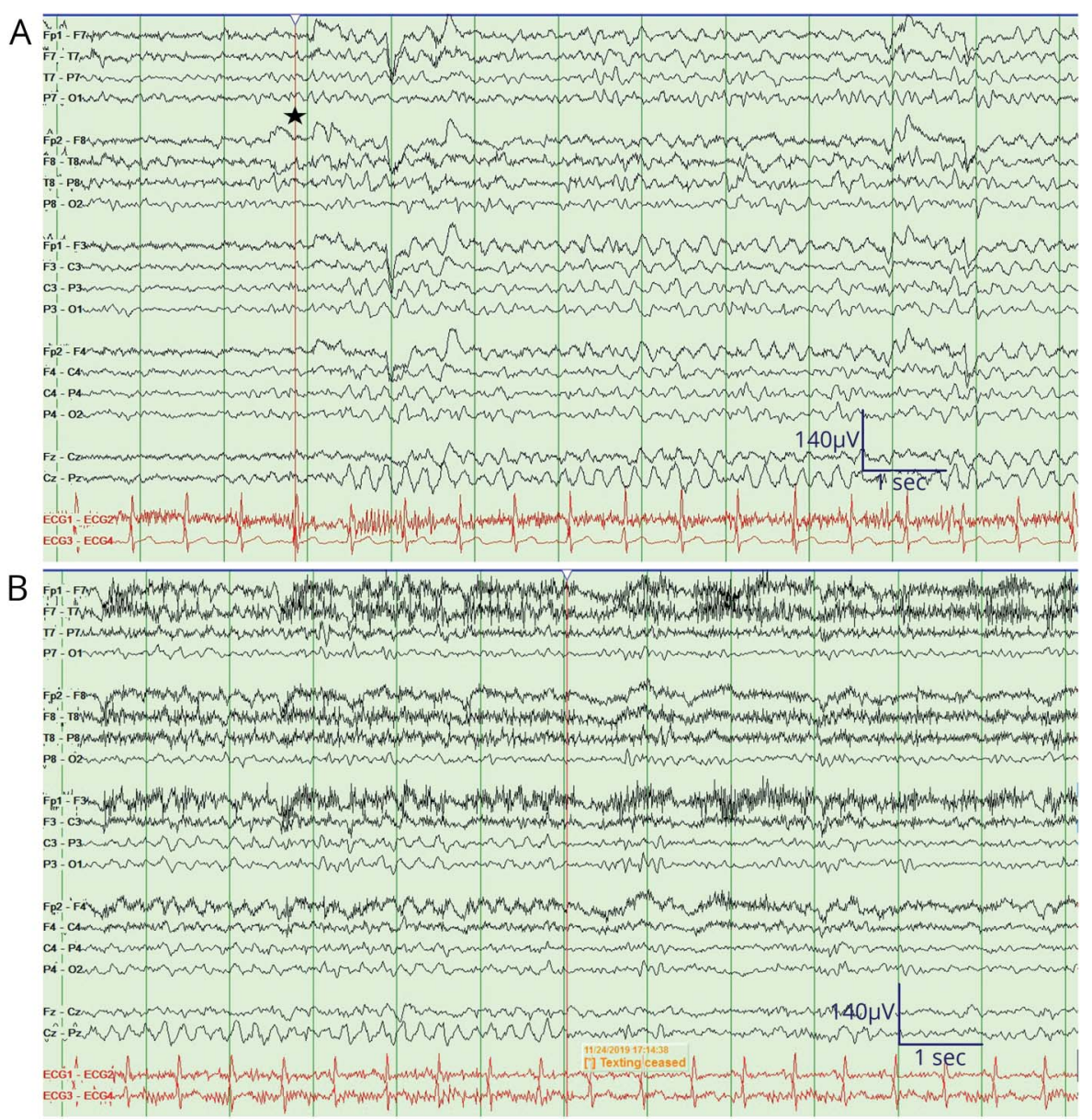

(A) EEG demonstrating bilateral 5-Hz monomorphic bursts of theta with frontocentral predominance that correlated with active texting (black star). (B) This pattern ceased when the patient stopped texting (red line). EEGs are presented in an anterior-posterior bipolar montage, sensitivity $7 \mu \mathrm{V} / \mathrm{mm}$, filters $1-70 \mathrm{~Hz}$.

A 39-year-old woman underwent epilepsy monitoring for differential diagnosis. During video EEG, a reproducible, time-synched, bilateral $5-\mathrm{Hz}$ frontocentral theta rhythm was present while text messaging on her smartphone (figure A). This pattern appeared only with active texting (figure B).

The texting rhythm is a recently recognized EEG pattern reported in up to $22.6 \%-24.5 \%$ of adults. ${ }^{1}$ It is related to cortical processing associated with personal electronic devices. ${ }^{2}$
Correspondence

Dr. Hanrahan

Brian_Hanrahan@

URMC.Rochester.edu

\section{MORE ONLINE}

$\rightarrow$ Teaching slides

links.lww.com/WNL/

B207

From the Department of Neurology (B.H.), University of Rochester Medical Center, NY; and Department of Neurology (W.O.T.), Mayo Clinic, Jacksonville, FL. Go to Neurology.org/N for full disclosures. Funding information and disclosures deemed relevant by the authors, if any, are provided at the end of the article. 
Brief durations occur with abbreviated texting as brief as several seconds. Electroencephalographers need to be aware of this novel waveform to distinguish it from an abnormal epileptiform pattern or evidence of cerebral dysfunction.

\section{Study funding}

No targeted funding reported.

\section{Disclosure}

The authors report no disclosures relevant to the manuscript. Go to Neurology.org/N for full disclosures.

\section{Appendix Authors}

\begin{tabular}{lll}
\hline Name & Location & Contribution \\
\hline $\begin{array}{l}\text { Brian } \\
\text { Hanrahan, } \\
\text { MD }\end{array}$ & $\begin{array}{l}\text { University of } \\
\text { Rochester Medical } \\
\text { Center, NY }\end{array}$ & $\begin{array}{l}\text { Identified case study patient for } \\
\text { manuscript and drafting of the } \\
\text { manuscript }\end{array}$ \\
$\begin{array}{l}\text { William O. } \\
\text { Tatum, DO }\end{array}$ & $\begin{array}{l}\text { Mayo Clinic, } \\
\text { Jacksonville, FL }\end{array}$ & $\begin{array}{l}\text { Drafting and revision of the } \\
\text { manuscript }\end{array}$ \\
\hline
\end{tabular}

\section{References}

1. Tatum WO, DiCiaccio B, Kipta JA, Yelvington KH, Stein MA. The texting rhythm: a novel EEG waveform using smartphones. J Clin Neurophysiol 2016;33:359-366.

2. Tatum WO, DiCiaccio B, Yelvington K. Cortical processing during smartphone text messaging. Epilepsy Behav 2016;59:117-121. 


\section{Neurology}

\section{Teaching NeuroImages: Texting rhythm: A common EEG finding in the era of smartphone use \\ Brian Hanrahan and William O. Tatum IV}

Neurology 2020;95;e3454-e3455 Published Online before print September 4, 2020

DOI 10.1212/WNL.0000000000010757

This information is current as of September 4, 2020

\section{Updated Information \& Services}

References

Citations

Subspecialty Collections

Permissions \& Licensing

Reprints including high resolution figures, can be found at: http://n.neurology.org/content/95/24/e3454.full

This article cites 2 articles, 0 of which you can access for free at: http://n.neurology.org/content/95/24/e3454.full\#ref-list-1

This article has been cited by 1 HighWire-hosted articles: http://n.neurology.org/content/95/24/e3454.full\#\#otherarticles

This article, along with others on similar topics, appears in the following collection(s):

EEG

http://n.neurology.org/cgi/collection/eeg_

EEG; see Epilepsy/Seizures

http://n.neurology.org/cgi/collection/eeg_see_epilepsy-seizures

Epilepsy monitoring

http://n.neurology.org/cgi/collection/epilepsy_monitoring_

Other Education

http://n.neurology.org/cgi/collection/other_education

Video/ EEG use in epilepsy

http://n.neurology.org/cgi/collection/video_eeg_use_in_epilepsy

Information about reproducing this article in parts (figures,tables) or in its entirety can be found online at:

http://www.neurology.org/about/about_the_journal\#permissions

Information about ordering reprints can be found online:

http://n.neurology.org/subscribers/advertise

Neurology ${ }^{\circledR}$ is the official journal of the American Academy of Neurology. Published continuously since 1951, it is now a weekly with 48 issues per year. Copyright (C 2020 American Academy of Neurology. All rights reserved. Print ISSN: 0028-3878. Online ISSN: 1526-632X.

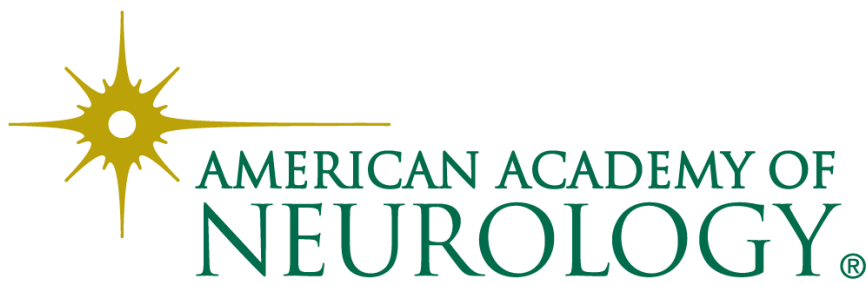

